\title{
Keberadaan Video Coronavirus Di Channel Youtube
}

\author{
Rachmaniar \\ Program Studi Ilmu Komunikasi, Fakultas Ilmu Komunikasi, Universitas Padjadjaran \\ Jl. Raya Bandung-Sumedang Km. 21, Jatinangor 45363 \\ Email:rachmaniar@unpad.ac.id
}

\begin{abstract}
ABSTRAK
Penelitian ini dilakukan untuk menganalisis budaya virtual dari Video Coronavirus - Cara Mencegah Virus Corona dan Kenali Gejalanya di channel YouTube Majalah Bobo, dilihat dari komentar netizen terkait dengan video yang diupload tersebut. Metode yang digunakan untuk penelitian ini adalah metode kualitatif melalui pendekatan etnografi virtual untuk menganalisis keberadaan Video Coronavirus - Cara Mencegah Virus Corona dan Kenali Gejalanya di channel YouTube Majalah Bobo. Objek utama penelitian ini adalah Video Coronavirus - Cara Mencegah Virus Corona dan Kenali Gejalanya di channel YouTube Majalah Bobo. Teknik pengumpulan data dilakukan melalui observasi partisipatif dan studi literatur. Hasil penelitian ini menunjukkan bahwa budaya virtual yang terbentuk atas komentar netizen terkait Video Coronavirus - Cara Mencegah Virus Corona dan Kenali Gejalanya di channel YouTube Majalah Bobo adalah, yang pertama netizen memberikan pernyataan positif untuk video yang diupload, dan hal ini meliputi pernyataanpernyataan untuk video, corona, dan Majalah Bobo. Kemudian netizen mengajukan pertanyaan-pertanyaan dan memberikan jawaban-jawaban, dan ini meliputi pertanyaan dan jawaban terkait video dan corona. Dan yang terakhir netizen memberikan komentar yang berorientasi pada diri sendiri, menyangkut pernyataan dan pertanyaan.
\end{abstract}

Kata kunci: coronavirus, youtubu, majalah, netizen.

\begin{abstract}
This research was conducted to analyze the virtual culture of Coronavirus Video - How to Prevent Corona Virus and Recognize the Symptoms on Bobo Magazine YouTube channel, seen from netizens comments related to the uploaded video. The method used for this research is a qualitative method through a virtual ethnographic approach to analyze the existence of Coronavirus Video - How to Prevent Corona Virus and Identify Symptoms on the Bobo Magazine YouTube channel. The main object of this research is Coronavirus Video - How to Prevent Corona Virus and Identify Symptoms on the YouTube channel Bobo Magazine. Data collection techniques are done through participatory observation and study of literature. The results of this study indicate that the virtual culture formed by netizens comments related to Coronavirus Video - How to Prevent Corona Virus and Identify Symptoms on YouTube channel Bobo Magazine is, the first netizens gave positive statements for uploaded videos, and this includes statements for videos, corona, and Bobo Magazine. Then netizens ask questions and provide answers, and this includes questions and answers related to video and corona. And finally, netizens provide self-oriented comments regarding statements and questions.
\end{abstract}

Keywords: coronavirus, youtube, Magazine, netizen.

\section{Pendahuluan}

Wabah coronavirus dimulai di kota Wuhan, Cina pada Desember tahun lalu. Bahaya potensial dari virus ini menjadi perhatian global ketika Dr. Li Wenliang dari sebuah rumah sakit di Wuhan berbagi pengetahuan yang dimilikinya dengan sesama dokter di WeChat terkait virus novel corona pada 30 Desember 2019.

Kota itu mulai melaporkan kematian pada 22 Januari. Dr. Li, yang pertama kali dituduh menyebarkan tipuan oleh polisi setempat, meninggal pada 7 Februari dalam usia 34 tahun. Ia kemudian dikonfirmasi telah terinfeksi seorang pasien virus corona yang berada di bawah pengawasannya. .

Pada tanggal 11 Maret 2020, WHO menyatakan bahwa sekitar 70 persen dari 7,8 miliar populasi di dunia rentan terinfeksi oleh virus. Indonesia menjadi salah satu negara yang rentan dengan virus tersebut. Pemodelan oleh sekelompok ahli matematika pun dilakukan. Universitas Indonesia menyatakan bahwa 
puncak penularan di Indonesia akan terjadi pada 16 April dan kemudian secara bertahap menghilang antara Mei dan awal Juni. Hal tersebut dapat terjadi jika langkah-langkah tertentu, seperti physical distancing dan berdiam diri di rumah dilakukan. Tanpa langkah-langkah mitigasi yang serius, puncak penularan akan berlanjut pada 4 Juni hingga September.

Ahli lain menyatakan bahwa puncak penularan di Indonesia akan terjadi pada 2 Mei dengan asumsi bahwa langkah-langkah seperti physical distancing dan berdiam diri di rumah dilakukan oleh sebagian besar masyarakat Indonesia. Intinya adalah siklus virus dapat terputus karena adanya sikap publik.

Satuan Tugas Covid-19, Doni Monardo menyebut bahwa disiplin mengikuti himbauan pemerintah menjadi solusi terputusnya penyebaran virus corona. Kurangnya kerja sama dari publik akan membuat kebijakan apa pun menjadi tidak berguna, dan penyebaran virus pun terus berlangsung. Untuk itu pemerintah Indonesia terus menghimbau masyarakat agar ketat melakukan jarak fisik dan mengenakan masker wajah di mana pun mereka berada. Bahkan pada pertengahan Maret, sejumlah daerah di Indonesia telah memutuskan untuk membatasi kegiatan publik, menutup sekolah, dan tujuan wisata sebagai bentuk memutuskan penyebaran virus corona 2019 (COVID-19).

Banyak dari langkah-langkah ini bahkan datang sebelum pengumuman Presiden Joko "Jokowi" Widodo menghimbau masyarakat di seluruh pelosok nusantara untuk menjaga jarak satu sama lain dan bekerja serta belajar di rumah. Pemerintah Jakarta mengumumkan pada tanggal 14 Maret 2020 bahwa mereka akan menutup sekolah di seluruh kota dan menunda semua ujian selama dua minggu kedepan. Siswa di Jakarta akan belajar melalui pembelajaran jarak jauh. Hal ini dilakukan saat diketahui bahwa ada beberapa anak dinyatakan positif COVID-19, dan bisa menjadi pembawa virus serta menginfeksi orang dewasa. Pemerintah DKI pun meminta warga untuk membatasi kegiatan di luar rumah mereka, kecuali untuk hal-hal mendesak. , Pertemuan publik termasuk acara keagamaan dan pernikahan adalah hal yang harus dibatalkan.

Pernikahan dapat diadakan di bawah langkah-langkah ketat, yang meliputi ketersediaan ruang isolasi untuk setiap tamu yang sakit, termometer untuk mengukur suhu tamu, pembersih tangan di pintu masuk dan keluar, serta larangan jabat tangan dan interaksi fisik lainnya. Lalu juga pemerintah DKI untuk sementara waktu menutup beberapa tempat hiburan yang dimiliki oleh pemerintah, termasuk Taman Impian Ancol, Kebun Binatang Ragunan dan Monumen Nasional. Acara Car Free Day mingguan di Jl. Sudirman dan J. MH Thamrin juga diskors selama dua minggu. Namun, transportasi umum, layanan publik, pusat kesehatan masyarakat serta kantor walikota dan gubernur akan tetap terbuka.

Di Surakarta, Jawa Tengah, pemerintah kota menyatakan status kejadian luar biasa (KLB) setelah kematian seorang pasien COVID-19 di Rumah Sakit Umum Moewardi terjadi pada tanggal 18 Maret 2020. Walikota Surakarta FX Hadi "Rudy" mengikuti keputusan Gubernur Jawa Tengah Ganjar Pranowo untuk menyatakan status yang sama di seluruh Jawa Tengah. Kota ini telah menghentikan sementara acara publik seperti Car Free Day dan pertunjukan seperti drama tradisional Sriwedari dan Ketoprak Balekambang selama 14 hari.

Dinas Kesehatan Surakarta telah memerintahkan 62 orang yang melakukan kontak dengan COVID-19 pasien di kota untuk mengisolasi diri dengan tinggal di rumah. Gubernur Jawa Tengah telah mengumumkan penutupan sementara semua sekolah di provinsi tersebut dan memerintahkan sekolah untuk menggunakan metode pembelajaran online selama 14 hari kedepan. Ganjar juga menginstruksikan pembatasan dan pembatalan pertemuan publik besar di seluruh provinsi, termasuk Car Free Day, berkemah, dan study tour.

Di Malang, Jawa Timur, putaran ketujuh dari Indonesianx League Basketball (IBL) Pertamax, yang seharusnya berlangsung pada tanggal 20 Maret 2020 dibatalkan setelah Asosiasi Bola Basket Indonesia (Perbasi). Klub-klub bola basket yang berpartisipasi dan para sponsor sepakat untuk memprioritaskan keamanan atlet dan penonton.

Gubernur Jawa Barat Ridwan Kamil telah mengumumkan keputusan untuk menerapkan pembelajaran online selama dua minggu, mulai 16 Maret 2020. Sepanjang minggu pertama di rumah, Ridwan Kamil berharap anak-anak akan belajar tentang penyakit COVID-19 dan bagaimana melindungi diri mereka sendiri. Anak-anak akan memahami instruksi COVID-19, mereka akan menyebarkan pengetahuan tentang COVID19 kepada orang tua, tetangga, dan teman mereka di media sosial.

Hal ini perlu dilakukan karena corona virus bukan sekedar virus. Virus ini atau Sars-CoV-2 dan penyakit yang disebabkannya, Covid-19, sangat mematikan dan mudah menular antar manusia atau bahkan dari sisa-sisa korban. Lebih dari 1,5 juta orang Indonesia dapat tertular penyakit ini tanpa langkah-langkah serius yang 
dikerahkan untuk memutus siklus virus, tanpa pasokan peralatan perlindungan pribadi yang memadai atau tanpa layanan medis yang sehat.

Siapapun berpotensi tertular virus hanya dengan memegang gagang pintu yang sebelumnya disentuh oleh orang yang terinfeksi. Jika setelah itu mereka menyentuh hidung, mulut atau mata mereka, virus akan berlanjut ke sistem pernapasan mereka. Inilah sebabnya mengapa mencuci tangan - seperti yang seharusnya diketahui semua orang sekarang menjadi kunci untuk menghindari penularan virus. Siapapun harus terbiasa dengan kebiasaan sosial baru, yaitu membawa sabun atau pembersih tangan ke mana pun bepergian.

Mengenakan masker adalah cara lain yang efektif untuk mencegah infeksi ketika orang-orang berada di tempat umum atau dalam pertemuan dengan orang lain.

Hal tersebut terus disampaikan oleh pemerintah. Konten-konten media social pun ramai-ramai membahas tentang kebiasaan baru ini.. Tercatar beberapa media sosial, seperti facebook, instagram, ataupun YouTube memiliki konten-konten himbauan semacam ini. Salah satu channel YouTube yang juga memiliki konten terkait corona virus - pencegahan dan gejalanya adalah channel YouTube Majalah Bobo. Dalam video ini disampaikan animasi-animasi yang mengedukasi netizen guna terhindar dari virus korona. Di dalam video ini juga diinformasikan terkait gejala-gejala yang biasa dialami oleh penderita covid-19.

Video berjudul corona virus - Cara Mencegah Virus Corona dan Kenali Gejalanya ini dipublikasikan tanggal 29 Januari 2020, jauh sebelum himbauan physical distancing dan penggunaan masker disampaikan pemerintah.. Atas hal tersebut, penulis menjadi tertarik untuk melihat keberadaan video tersebut dilihat dari komentar yang disampaikan netizen. Dari hal ini, penulis dapat mengetahui bagaimana budaya virtual yang terbentuk atas video yang diupload tersebut. Untuk menjawab pertanyaan penelitian ini, penulis menggunakan pendekatan kualitatif dengan metode etnografi virtual.

\section{Metode Penelitian}

Penelitian kualitatif menawarkan pendekatan sistematis untuk mempelajari fenomena dalam konteks tertentu (Gast, 2010). Ini adalah eksplorasi dan upaya untuk mengembangkan penjelasan (Lincoln \& Guba, 1985). Fenomena diperiksa secara luas dan mendalam, yang sangat berguna ketika masalah berada pada tahap awal (Babbie, 1989). Data sering dihasilkan melalui wawancara, observasi langsung, hingga analisis artefak, dokumen dan catatan budaya, bahan visual atau pengalaman pribadi (Denzin \& Lincoln, 1994).

Berg dan Howard (2012) mencirikan penelitian kualitatif sebagai makna, konsep, definisi, metafora, simbol dan deskripsi hal-hal. Karenanya, pendekatan penelitian kualitatif menyediakan data berlimpah tentang orang-orang dan situasi kehidupan nyata (De Vaus, 2014, p6; Leedy dan Ormrod, 2014). Ketergantungan pada pengumpulan data primer non-numerik seperti kata-kata dan gambar oleh peneliti yang berfungsi sebagai instrumen sendiri membuat penelitian kualitatif sangat cocok untuk memberikan fakta dan informasi deskriptif (Johnson dan Christensen, 2012, p29-37). Bogdan dan Biklen (1982) menyatakan bahwa penelitian kualitatif adalah deskriptif yang datanya dikumpulkan dalam bentuk kata atau gambar daripada angka.

Sementara etnografi virtual adalah metode etnografi yang dilakukan untuk melihat fenomena sosial dan kultur pengguna di ruang siber (Nasrullah, 2014: 171ᄀ). Etnografi virtual mempertanyakan asumsi yang sudah berlaku secara umum tentang internet, menginterpretasikan sekaligus reinterpretasi internet sebagai sebuah cara sekaligus medium yang digunakan untuk berkomunikasi, merupakan "ethnography in, of and trough the virtual” - interaksi tatap muka atau face to face tidak diperlukan (Hine, 2001).

Tom Boellstorff, professor di bidang antropologi University of California, US menyatakan bahwa penelitian etnografi virtual, pada dasarnya memiliki prinsip-prinsip yang sama dengan penelitian etnografi, dimana proses melakukan dan membangun etnografi menggunakan lingkungan virtual online sebagai lokasi penelitian.

Boellstorf menyatakan bahwa pengumpulan data penelitian diluar lokasi (dunia virtual) penelitian sama saja dengan melanggar prinsip "in their own term", karena bagaimanapun juga segala sesuatu memiliki makna dalam konteksnya sendiri. 
Dalam etnografi virtual, wawancara dan survei dapat digantikan oleh koleksi/arsip yang sudah ada yang berasal dari informasi yang melimpah di lingkungan online seperti situs jejaring sosial dan forum internet. Informasi dapat ditemukan dan diarsipkan dari internet tanpa harus dicatat dan ditulis seperti etnografer tradisional (Evans, 2010:2).

\section{Hasil dan Pembahasan}

Berdasarkan keberadaan Video Coronavirus (Cara Mencegah Virus Corona dan Kenali Gejalanya) di Channel YouTube Majalah Bobo, diketahui bahwa netizen memiliki empat budaya virtual, yaitu memberikan pernyataan positif, mengajukan pertanyaan, menjawab pertanyaan, dan memberikan komentar yang berorientasi pada diri sendiri.

Tidak ada satu pun netizen yang memberikan pernyataan negative, kritik, atau menghujat.

Pernyataan Positif

Netizen memberikan pernyataan positif untuk video yang diupload, dan hal ini meliputi pernyataanpernyataan untuk video, corona, dan Majalah Bobo

\section{Pernyataan Positif terkait Video}

Untuk pernyataan positif terkait video, sebagian besar netizen menyatakan bahwa video yang diupload adalah video yang bagus, bermanfaat, dan baik untuk mengedukasi anak, orangtua, atau siapapun dalam rangka mencegah dan mengenali gejala virus corona. Video tersebut mudah dimengerti dan dipahami. Untuk itu banyak netizen yang berterimakasih pada Majalah Bobo karena telah mengupload video tersebut. Ada juga netizen yang meminta Majalah Bobo agar mengupload video-video lain yang memiliki nilai edukasi.

Yang juga menarik terkait pernyataan positif netizen untuk video adalah banyaknya netizen yang meminta izin untuk menyimpan atau membagikan Video Coronavirus (Cara Mencegah Virus Corona dan Kenali Gejalanya) di Channel YouTube Majalah Bobo. Netizen merasa video tersebut tepat untuk disimpan dan dibagikan.

Banyak netizen yang menyimpannya untuk tugas sekolah dan tugas kuliah. Ada juga netizen yang menyimpannya untuk bahan ajar di sekolah. Jadi disini terlihat bahwa selain siswa atau mahasiswa, pengajar pun menjadikan video ini sebagai referensi pembelajaran.

Lalu untuk netizen yang izin membagikan video tersebut, video tersebut rencananya akan diupload ulang di media social yang mereka miliki, seperti Facebook dan Instagram. Dan ini tentu dengan menyertakan sumber asli dari pemilik videonya.

2. Pernyataan Positif terkait Corona

Selanjutnya terkait pernyataan positif netizen untuk korona adalah banyak netizen yang mendoakan agar seluruh warga Indonesia dan netizen lain selamat, sehat, dan terhindar dari virus corona. Bahkan beberapa netizen dengan informative memberikan beberapa info terkait corona, seperti:

- Info daerah yang terkena positif corona

- Info untuk tidak sering bersentuhan dengan benda-benda di area public, seperti pegangan pintu minimarket atau mall, tombol atm, tombol tiket parkiran, dan sebisa mungkin untuk menghindari wc umum

- Info untuk memperbanyak konsumsi buah-buah dan dan sayuran segar, serta mengurangi makanan berlemak, manis, dan gorengan

- Info untuk rajin mengkonsumsi air putih, dan menghindari mengkonsumsi minuman yang dingin atau manis

- Info untuk teratur berolahraga

- Info untuk teratur berjemur di bawah sinar matahari

- Info untuk istirahat malam yang cukup dan tepat waktu dengan mematikan lampu 
- Info untuk rajin mencuci tangan, terutama sebelum makan, setelah memegang uang, serta setelah kembali dari tempat umum

- Info untuk banyak berdiam dalam rumah, dan menghindari bepergian keluar rumah

- Info untuk menutup mulut menggunakan tisu atau baju saat bersin

\section{Pernyataan Positif terkait Majalah Bobo}

Lalu untuk pernyataan positif terkait Majalah Bobo, banyak netizen yang merasa rindu dengan Majalah Bobo. Majalah Bobo adalah majalah netizen sejak kecil, dan ternyata hingga sekarang masih eksis dan bertahan. Netizen juga memberikan pernyataan bahwa Majalah Bobo adalah majalah yang mereka sukai, majalah yang hebat, majalah yang bagus, dan majalah yang mengedukasi. Netizen ingin Majalah Bobo terus sukses dan mneginspirasi.

\subsection{Pertanyaan}

Kemudian netizen mengajukan pertanyaan-pertanyaan, dan ini meliputi pertanyaan terkait video dan corona

1. Pertanyaan terkait Video

Untuk pertanyaan terkait video, sebagian besar netizen bertanya cara membuat video animasi tersebut, editing, serta backsound yang ada dalam video tersebut.

Berdasarkan pertanyaan terkait ketiga hal tersebut diatas menandakan bahwa netizen memiliki keingian yang tinggi untuk bisa membuat video yang bagus, melakukan editing yang tepat, serta menggunakan backsound yang sesuai.

Namun sayangnya netizen tidak mempunyai kemampuan melakukan tiga hal itu, dan ini sesungguhnya bisa menjadi peluang bagi wirausaha untuk membuat program atau pelatihan membuat dan mengedit video animasi.

2. Pertanyaan terkait Corona

Selanjutnya terkait pertanyaan netizen untuk corona adalah netizen-netizen bertanya mengenai:

- Perbedaan virus corona dan flu

- Masker yang sebaiknya digunakan orang sakit dan orang sehat

- Obat corona

- Olahraga yang sebaikanya dilakukan

- Makanan yang sebaiknya dikonsumsi

\subsection{Jawaban}

Hal lain yang juga dilakukan netizen dalam kolom komentar Video Coronavirus (Cara Mencegah Virus Corona dan Kenali Gejalanya) pada Channel YouTube Majalah Bobo adalah netizen memberikan jawaban atas pertanyaan yang diajukan netizen lain. Dan jawaban-jawaban yang diberikan adalah jawaban-jawaban terkait video dan corona.

\section{Jawaban terkait Video}

Disini netizen memberikan jawaban terkait pertanyaan pembuatan video animasi. Netizen ini menjawab bahwa untuk membuat video animasi, netizen lain bisa menggunakan aplikasi powtoon

\section{Jawaban terkait Corona}

Untuk pertanyaan-pertanyaan terkait corona, netizen menjawab bahwa untuk membedakan virus corona dan flu, sebaiknya netizen pergi ke dokter untuk memastikan segala sesuatunya. Begitu pun dengan obat yang dikonsumsi, sebaiknya dikonsultasikan dengan dokter yang ahli di bidang tersebut. 
Netizen juga menjawab bahwa obat terbaik yang bisa dilakukan saat ini adalah memperkuat system imun yang dimiliki, dan ini bisa dilakukan melalui olahraga yang teratur, rajin mencuci tangan, serta mengkonsumsi makanan dan minuman tertentu, seperti kurma, kacang hijau dan jagung rebus, wedang jahe, campuran susu, jahe, dan sere. Lalu untuk masker orang sakit dan orang sehat, netizen menjawabnya bahwa masker orang sakit sebaiknya menggunakan masker medis yang terdiri dari tiga palisan dan biasanya berwarna hijau.

\subsection{Komentar Berorientasi Diri Sendiri}

Terakhir untuk komentar berorientasi pada diri sendiri, ditemukan bahwa netizen memberikan komentar berupa pernyataan dan pertanyaan

1. Pernyataan

- Penggunaan masker

Disini ada netizen yang mengïnformasikan bahwa dirinya kerap menggunakan masker sehingga kecil kemungkinan terkena virus corona.

- Gejala tubuh

Disini netizen menginformasikan bahwa dirinya mengalami gejala yang sama seperti yang disampaikan video. Lalu ada juga netizen yang menyampaikan bahwa dirinya memiliki nafas pendek, tetapi diketahui nafas tersebut akibat rokok. Lalu ada juga netizen yang menginformasikan bahwa dirinya sempat mengalami panas, batuk, dan demam. Tetapi setelah itu diketahui bahwa netizen tidak mengalami corona, melainkan cacar.

- Channel YouTube

Disini ada netizen-netizen yang meminta netizen lain untuk mengunjungi, like dan subscribe channel YouTube yang dimilikinya atau dimiliki anaknya.

\section{Pertanyaan}

Lalu untuk pertanyaan, disini ditemukan netizen-netizen yang bertanya terkait gejala yang dialaminya, seperti batuk berdahak, batuk kering, radang tenggorokan, bersin, demam, pilek, sesak nafas. Gejala-gejala tersebut termasuk gejala corona atau bukan.

Temuan dalam penelitian ini adalah, Channel YouTube Majalah Bobo telah berhasil membuat netizen memberikan pernyataan positif terkait video, dan tidak ada satu pun netizen yang memberikan pernyataan negative, mengecam, atau menghujat video yang diupload. Kecenderungan netizen menyukai video tersebut. Lalu diketahui juga bahwa untuk tugas-tugas sekolah atau video referensi, ternyata netizen lebih memilih jalan pintas dengan menyimpan atau membagi video tersebut. Lebih banyak netizen yang berpikir untuk mengambilnya daripada membuatnya. Hal ini tentu harus menjadi perhatian khusus betapa netizen tanah air lebih memilih jalan yang mudah untuk segala sesuatunya.

Terakhir yang juga menarik, ada beberapa komunikasi yang berlangsung dua arah antara netizen satu dengan netizen lainnya. Dan ini menjadi menarik karena respon-respon yang diberikan adalah respon yang sesuai antara pertanyaan dan jawaban. Sementara impervious response (respon kosong) dilakukan oleh pemilik channel YouTube dengan netizen. Pemilik channel YouTube sama sekali tidak memberikan respon apapun terhadap pernyataan atau pertanyaan yang disampaikan netizen. Dan ini sangat disayangkan.

\section{Simpulan}

- Berdasarkan keberadaan Video Coronavirus (Cara Mencegah Virus Corona dan Kenali Gejalanya) di Channel YouTube Majalah Bobo, diketahui bahwa netizen memiliki empat budaya virtual, yaitu memberikan pernyataan positif, mengajukan pertanyaan, menjawab pertanyaan, dan memberikan komentar yang berorientasi pada diri sendiri. Tidak ada satu pun netizen yang memberikan pernyataan negative, kritik, atau menghujat. 
- Netizen memberikan pernyataan positif untuk video yang diupload, dan hal ini meliputi pernyataanpernyataan untuk video, corona, dan Majalah Bobo

- Netizen mengajukan pertanyaan-pertanyaan dan memberikan jawaban-jawaban, dan ini meliputi pertanyaan dan jawaban terkait video dan corona

- Netizen memberikan komentar yang berorientasi pada diri sendiri, dan ini menyangkut pernyataan dan pertanyaan

\section{Daftar Pustaka}

1. Babbie, E. 1989. The Practice of Social Research, 5th edition. Belmont CA: Wadsworth.

2. Berg, B. L. \& Howard, L. 2012. Qualitative Research Methods for the Social Sciences. (8th ed). USA: Pearson Educational Inc.

3. Boellstorff, Tom. 2008. Coming of Age in Second Life : An Anthropologist Explores The Virtually Human. New Jersey: Princenton University Press.

4. De Vaus, D. A. 2014. Surveys in Social Research. (6th ed). Australia: UCL Press

5. Denzin, N.K. \& Lincoln, Y.S. 1994. Handbook of Qualitative Research. Thousand Oaks: Sage.

6. Gast, D. L. 2010. Single Subject Research Methodology in Behavioral Sciences. New York: Routledge.

7. Hine, Christine. 2001. Virtual Ethnography. London: Sage Publication Ltd.

8. Johnson, B. \& Christensen, L. 2012. Educational Research, Qualitative, Quantitative and Mixed Approach. (4th ed). California: SAGE Publication.

9. Leedy, P. \& Ormrod, J. E. 2014. Practical Research Planning and Design. (10th ed). Edinburgh: Pearson Educational Inc.

10. Lincoln, Y. S. \& Guba, E. G. 1985. Naturalistic Iinquiry. Beverly Hills, CA: Sage

11. Nasrullah, Rulli. 2014. Teori dan Riset Media Siber (Cybermedia). Jakarta:Kencana 